\title{
Cossuridae (Annelida: Polychaeta: Sedentaria) from Australian and Adjacent Waters: the First Faunistic Survey
}

\author{
ANNA ZHADAN \\ Biological Faculty, Moscow State University, Leninskie Gory, 1-12, Moscow 119234, Russia \\ azhadan@wsbs-msu.ru
}

\begin{abstract}
The collection of Cossuridae at the Australian Museum was investigated. Nine species were identified. Most specimens were from New South Wales and Queensland, but some specimens were also from Victoria, New Zealand, Fiji, Borneo, and the Philippines. Three new species were described: Cossura hutchingsae n.sp., C. keablei n.sp., and C. queenslandensis n.sp. Cossura consimilis Read, 2000 was redescribed using non-type material. Cossura aciculata (Wu \& Chen, 1977) was identified from the coast of Borneo and the Philippines for the first time, and intraspecific variability in the number of thoracic chaetigers noted for that species. Three species, $C$. cf. ginesi, $C$. cf. longocirrata and $C$. cf. pygodactylata, were found to be morphologically similar to $C$. ginesi, $C$. longocirrata, and C. pygodactylata, respectively, but probably represent new species as they were found far from the known areas of the listed species. A key of the known cossurid species of Australian and adjacent waters is given, and taxonomical characteristics of Cossuridae are discussed.
\end{abstract}

ZHADAN, ANNA. 2015. Cossuridae (Annelida: Polychaeta: Sedentaria) from Australian and adjacent waters: the first faunistic survey. Records of the Australian Museum 67(1): 1-24.

Cossuridae Day, 1963 is a small family of benthic polychaetes. Cossuridae is composed of 23 species, all in the genus Cossura. Cossurids inhabit shallow marine sediments, and, in deep-sea habitats, they also commonly inhabit mixed sand and mud. In Australian waters, the family has been reported along the southern and eastern coasts, but specific species have not been previously identified (Hutchings \& Murray, 1984; Hutchings, 2000). One species, Cossura consimilis Read, 2000, was identified in New Zealand.

Cossuridae species are difficult to distinguish morphologically and do not have many taxonomic characteristics. Some of the described species are very similar and differ by only one feature. For example, C. longocirrata Webster \& Benedict, 1887 and C. pygodactylata Jones, 1956 differ by the presence of pygidial intercirral appendages in the latter, and $C$. soyeri Laubier, 1963 and $C$. consimilis differ by the positioning of the branchial filament. Some species have been described using incomplete specimens; the descriptions of those species are too short, and the most important characteristics of those species remain unknown (see Read, 2000 , table 1 for review). Taxonomic revision of this family with reinvestigation of type materials and a large number of specimens for each species to reveal intraspecific variability and molecular genetic methods is required.

The taxonomic characteristics used for the differentiation of cossurid species are as follows. Prostomium shape varies from conical (triangular from dorsal view) to round, trapezium-shaped and almost quadrangular. The length to width ratio of the prostomium is usually close to $1: 1$; refer to the discussion on the delineation of the prostomium and the peristomium below. The tip of the prostomium is never drawn and does not form a palpod as is the case in some 